\title{
Women and the war
}

The Great War, most people would have agreed at the time, was a male creation. Politicians, statesmen and kings bred it and soldiers fought and fed it. Thus far, this study has regarded those women within Bloomsbury whose aesthetic reactions to the conflict provide such a good starting point when examining the war in this context. What of other women, existing independently from that hot-house of creativity, but who felt similarly? Due to their status in society as a whole, women necessarily operated within a different cultural milieu to that of men - even when sharing an enlightened, liberal background with them, as within Bloomsbury and its circle. But women emerged from a range of backgrounds and contexts - including that of political agitation linked to specific political aims - whose motivation towards protest, when confronted by the specifics of war, became more individualistic in character and less a part of an organised 'movement' or liable to be led by the propaganda of the war-state.

Many women in the period leading up to the outbreak of the conflict could lay claim to a history of opposition; during the pre-war period one of the principal focal points of public dissent against the existing political structure had been the women's suffrage movement. This cause, by the nature of its specific political goals, had also been largely political in organisation, character and aspiration, though precepts of greater equality for women outside the political sphere - once they had achieved the vote - were meshed to hopes for the ultimate cultural emancipation of the female sex. It is interesting, then, to observe and comment upon the course taken by this swelling tide of political protest as it crashed violently against the rock of war; namely, that though the strength of dissent was dissipated to some extent, it by no means ran dry. Indeed, a modern commentator has stated that, 'Half the leading women in the British suffrage movement opposed the war'. ${ }^{1}$

Some women were able to formulate their opposition to the conflict on a personal level - over and above the political framework of women's suffrage through direct experience of nursing or simple observance from the Home Front as the casualties mounted. This 'truth' of the conflict led some women to question their position; not in their decision, in some cases, to nurse, but in stark terms of human suffering. The creation of maimed bodies and minds on an 
unprecedented scale began to be perceived as wrong - for whatever cause or nationality. Boundaries dissolved - those between nations as well as those that lay between propaganda and truth. The gilt was off war, as a friend of one of the women in this section, Mabel Dearmer, commented to her. Some women were intellectually opposed to the war and expressed their opinions - at no less strength - from a distance in their private conversations and writings. This form of expression of female opposition became the norm, as women found that other accessible outlets for protest were few and far between. Hence in the diaries, letters, memoirs and occasional fictions of some women we are able to observe their turning away from the general call to arms and mobilisation of opinion.

In the evening of 4 August 1914, during the final hours of peace (11 p.m. marked midnight in Berlin and hence a formal commencement of hostilities), a meeting was held at Kingway Hall in London in order to discuss the position of women and the women's movement in regard to the rapidly approaching conflict. This meeting marked a confluence of some of the various leading women's organisations of the day such as the Women's Co-operative Guild, the Women's Freedom League, the Women's Labour League, the National Federation of Women Workers and the sponsor of the meeting, the large National Union of Women's Suffrage Societies, which alone was able to declare one hundred thousand affiliated suffragists, six hundred societies and eight hundred pre-war new members a month. The various groups in attendance were not only British; representatives of the International Women's Suffrage Alliance from nations as far as Finland and Russia were present. The sister of General Sir John French, Charlotte Despard, was also present, although those twentieth-century symbols of suffrage - the Pankhursts and their Women's Social and Political Union were not. This could be seen as paradoxical given the militant nature of the Pankhursts and the relative non-militancy of the National Union of Women's Suffrage Societies. However, other groups such as the Women's Co-operative Guild possessed a history of opposition to war.

A few days after that Kingway Hall meeting, Christabel Pankhurst described the war as a 'horrible calamity' in The Suffragette and, more crucially in terms of this study, had already condemned the conflict as a 'mechanical and soulless massacre' in an earlier issue. To her, the war was a by-product of a civilisation that had been dangerously tilted by the weight of men's opinions and actions. In spite of these public declarations, Christabel Pankhurst soon joined her family and the other leaders of the Women's Social and Political Union in their support for the war which, it was decided, could take the form of a 'national militancy', though not all agreed: Emmeline Pankhurst was forced to denounce her daughters Sylvia and Adela for their public pacifism.

The Kingway Hall meeting of 4 August urged immediate mediation from non-belligerents in order to put the brakes on a situation which, it was felt, could soon escalate out of control. The meeting also resolved to call on women's 
organisations to 'offer their services' to the country at a time of national crisis, though precisely what form this offer of service was to take was unclear. These resolutions were taken immediately to Downing Street. Though there were some calls for strikes and stoppages, most of the women present at the meeting felt a need at this point, either collectively within their organisations or individually, to contribute something to their nation at war and for most this feeling, albeit temporarily, transcended the effort to obtain the vote. This feeling was echoed by women who had been agitating for suffrage in the country at large. Millicent Fawcett, the leader of the National Union of Women's Suffrage Societies, recognised this and later described the day as being one of the most miserable of her life, as she observed at a single stroke the cause of women's suffrage being postponed for an indefinite period. However, despite the electoral position of women remaining weak, in a parallel context, women could be said to have been in a stronger position in that they had had no voting power in the period leading up to the war and hence could not be held responsible for the international build-up of tension that had finally erupted in the summer of 1914. It was recognised by some that the world of hostility and tension had been created by men and this in turn could provide women with a somewhat greater moral freedom as to their personal reaction with regard to the war.

As observed in Chapter 2, freedom from conventional morality was one of the pillars supporting the philosophy of life that bound the individuals constituting the Bloomsbury Group together, both male and female. This freedom from convention served to fuel their responses to the war, as we have seen not only in the cases of the men such as J.M. Keynes and Duncan Grant - it was equally true of the daughters of Sir Leslie Stephen; Virginia Woolf and Vanessa Bell. But what of other women?

It is clear that women experienced a diversion of their political aspirations and energies regarding suffrage into anti-war thoughts and activities. What of women who simply desired to be involved in the war to a greater extent and whose subsequent experience facilitated a (sometimes unexpected) humanistic response to the shattered bodies and loss of life that they observed at close quarters? Although many women responded to their country's call by replacing men in the munitions factories, this response also sprang from a motivation to take advantage of the higher wages on offer in industry of national importance. Grief and strain marked the war experience of countless women; the uncertainty of the survival of a husband, wage-earner, father, brother or son darkened the wartime existence of many and while this may not have resulted in militant anti-war protest, a shared sense of bereavement over many months of unresolved conflict resulted in a simple wish, shared by many at the front, that the war be ended as soon as possible, whether by victory or negotiation. As Sylvia Pankhurst points out in her The Home Front, anti-war feeling and emotions were not limited to the arguing intellectuals, but were also to be found 'most firmly rooted' among those attempting to live normal lives in the small 
villages and towns of rural areas, where most cottages and homes contained photographs, many black-bordered, of soldier husbands and sons. ${ }^{2}$ Though not a pacifist himself, the author Wilfrid Ewart commented that for the women of England:

Death after all became a commonplace thing ... the ethics of sorrow changed, many people following simply instinct rather than the dictates of convention or of principle ... still the dominating note was tragedy. And if the war showed human nature at its least, it brought out, too, astonishing heights of faith, strength and courage in women as it did of 'heroism' in men. The divine humane spark burnt bright in each case. $^{3}$

One in whom the 'humane spark' which, when translated into action, burned particularly bright (and mentioned by Anne Wiltsher in her 'Most Dangerous Women' and Jo Vellacot in 'Feminist Consciousness and the First World War') ${ }^{4}$ was Catherine Marshall who, until 1915, was both the Parliamentary Secretary of the National Union of Women's Suffrage Societies and in control of one of the most active sections of the NUWSS, the Election Fighting Fund. She had spent most of the previous decade mustering support for women's suffrage and, as Jo Vellacot points out, like many other women campaigners, Marshall's ideals of suffrage sprang from a background of liberalism; she had absorbed J.S. Mill's Liberalism, for example, and in her case - as in that of others - suffrage (and, later, her pacifism) could be seen as a 'component' of her personal liberal ideals.

After the Women's International Congress of the Hague in April 1915 caused a split to occur in the NUWSS over education for Peace and support for that meeting, Marshall helped to found the British section of the Women's International League for Peace and Freedom, which had emerged from the meeting and which was, according to Vellacot, the most solid achievement of the feminist pacifists to emerge from the war. With the newly emergent freedom of choice of action available to the pre-war suffragists, Marshall then narrowed her work to suit her own goals, as much as Charlotte Despard did by moving from the Presidency of the Women's Freedom League at the start of the war to touring the country in support of a federated Europe by 1918 for the Women's Peace Crusade. Marshall worked for the National Council Against Conscription and also, by March 1916, for the No Conscription Fellowship. Within a matter of days of starting her work for the NCF, she had written on a daily basis (and with eventual success) to a holidaying Bertrand Russell appealing for his help. She also attended the National Convention of the NCF at Devonshire House. Marshall became one of the linchpins of that organisation, especially after many of the leading male activists began to be imprisoned after their individual tribunals.

Another in whom the 'humane spark' manifested itself in practical action (and who worked with Catherine Marshall for the NCF in London during the summer of 1916) was Helen Bowen Wedgwood, who later, as Mrs H. Pease, 
was to donate to the Imperial War Museum a substantial archive of letters to her from the many imprisoned conscientious objectors she assisted. ${ }^{5}$ She was the eldest of seven children and, like Frances Partridge, attended Newnham College, Cambridge. While there, she had been secretary of the Cambridge Fabian Society but had found the Fabians 'too slow' and had subsequently helped to form the University Socialist Society, though, as she later admitted, 'at no time was I a socialist in the accepted sense of the word' ${ }^{6}$ She found moral sustenance for her pacifism in her contacts with the Quakers (though never a Quaker herself) since she found their direct and clear-cut philosophy an immense relief amid the 'endless discussions' of the political pacifists. Wedgwood found it hard to always be seen as part of a minority and constantly questioned on the justification of one's position regarding the war at every meeting and dinner party.

Also in common with Frances Partridge, Wedgwood had been brought up in a family that believed strongly in the strength of the position of an individual and in his or her chosen course of action, without interference from others. Hence her preference for action over argument and her lack of encouragement of others not to volunteer while the voluntary system lasted. While at Newnham, she was impressed by the positions of academics such as Goldsworthy Lowes Dickinson on the war and their courage in facing the animosity of colleagues such as the 'last ditch dons' - academics who joined up only at the last minute and then for home defence only. When talk of conscription began to circulate, Wedgwood attended the first meeting of the Cambridge branch of the NCF and became its shadow secretary when the acting secretary was arrested. This activity was set against a background of personal tragedy when her cousin Cecil was killed on the Somme in 1915. She had little patience with those of supposed stature in the peace movement, such as politicians Snowden and Lansbury, both of whom she thought 'woolly-headed' (though genuine and kind). In her opinion, Bertrand Russell offered no help to the rank and file, and this coloured her view of other 'pacifist dons', some of whom she suspected of concealing jobs in the War Office. Suspicion was rife in a university town which, although devoid of the vast majority of its male students, was as much gripped by 'war fever' as anywhere else. For example, Wedgwood recalled a period when Catherine Marshall organised a watch on a railway station in order to make sure no conscientious objectors were taken abroad by the authorities surreptitiously. In addition, rumours abounded of a 'retired colonel' who supposedly invited to tea undergraduates suspected of being anti-war. An opportunity was thus engineered, it was said, for their rooms to be searched for incriminating material.

At the outbreak of war, Wedgwood's father, Josiah, had been Liberal MP for Newcastle under Lyme and had persuaded Winston Churchill to place him in the Armoured Cars, Royal Naval Division while his eldest son Charles, though only sixteen, was allowed to enlist in the 5th North Staffords (and later in the Armoured Cars, again through the influence of his father). After he was wounded 
in 1915, Wedgwood's father was forced to confine himself to parliamentary activities and a job at the War Office, courtesy of Churchill. While he supported conscription, he also supported the individual's right to choose the path of the conscientious objector. He soon became disillusioned with the War Office, however, describing the bureaucrats as 'vultures' waiting to see what they could get out of the country in terms of statistics and quantities. He then became a Lieutenant-Colonel in the Army and went to East Africa in early 1916.

It had been while her father was serving in Gallipoli that Wedgwood had met Clifford Allen for the first time, at a Fabian conference at Keswick and, by the time her father left the country for the second time, Wedgwood was much more involved with the NCF (she attended a conference in London in spring 1916). She had reached, through her own efforts and observations, a new stage in the development of her personal pacifism; she now described herself as a 'Tolstoyan pacifist', and by this time the strength of her anti-war stance and activities was largely recognised by her own family. This was demonstrated when one of her uncles, despite being a Major in the North Staffords, prevented his mother (Wedgwood's grandmother, who disapproved of her help for conscientious objectors) from stopping her allowance. The money, or lack of it, was not to be used to attempt to coerce Wedgwood away from the dictates of her individual conscience regarding the war and her place in relation to it.

It was at this point, in 1916, that Wedgwood's anti-war feeling took flight. She attended many tribunals and noted the names of individuals mentioned, to use as possible future contacts. The energy and enthusiasm involved in her antiwar activities resulted in her leaving Cambridge with a second class degree. This, however, had little effect on her practical work, and she moved back home to the Potteries to join the Stoke branch of the NCF with her sister, Rosamund. She spent much of her time keeping track of the latest arrests and courts martial and visiting those held in local guardrooms with letters from wives and mothers concealed in various guises - perhaps a devotional work of some kind (usually a prayer book) or in a letter purporting to come from a pious aunt. Wedgwood found that, on the whole, the soldiers she encountered at the guardrooms tended to be friendly and sometimes displayed a tacit appreciation of the plight of the conscientious objectors. She commented on the soldiers that, 'they had a sort of vague feeling that ... they all felt caught up in the machine ... which they were all helpless to escape'. She also noted a general respect amongst the objectors for those in the trenches and an awareness that however bad the treatment meted out in the prisons and guardrooms, it was as nothing compared to the hell of the front. The death of some of her friends and relatives in action, especially that of her cousin, convinced her more firmly of the rightness of her humanistic awareness of the tragic waste of the situation and of her practical response to her feelings; to her, the only logical course of action for those of an anti-war disposition was either to refuse to fight or to help those who made the refusal. 
In the autumn of 1916, Wedgwood started to work on behalf of the Women's Trade Unions in factories in the East End of London, though this proved too much for her (she felt unsuited to Trade Union work in particular) and returned to the Potteries. The following year saw her return to the capital, where she helped to found the 17 Club in Gerrard Street in the wake of the tide of hope for peace and a new world order that followed the Russian Revolution. However, with its unruly mixture of revolutionaries, anarchists and pacifists, she felt the club to be badly organised, and she returned to the Midlands in order to help her recently widowed Aunt Kat (whose husband had been killed at the front on Hill 60) and her three children. She re-established links with the Birmingham Quakers and tried her hand at market gardening, forestry and digging potatoes while passing on reports for the NCF, although most of the COs were now in prison or had accepted 'alternative' work (most of the North Staffordshire branch took this course). ${ }^{8}$

When her brother Charles, who had joined the Royal Flying Corps, was shot down over Germany and reported as missing and believed killed in the early autumn of 1918, Wedgwood's health broke down completely, and she went to housekeep for the daughter of her cousin who had been killed on the Somme. Despite her precarious health, she still managed to speak at open-air meetings on the situation in Russia and attend meetings of the local Women's Co-operative Guild. The end of the war was marked for her by the sound of the church clock striking again and by the news that her brother was alive and a prisoner in Germany. Typically, peace brought no rest; after continuing to agitate for the release of the remaining imprisoned COs (including George Horwell and his brother) and for an assurance from the authorities of no permanent conscription, she set to work once more, campaigning for better housing for the poor.

The women peace campaigners of the Great War who possessed a previous history of personal activism through the struggle for suffrage, were naturally at their most vocal and public (whether vilified or, in rare cases, supported by the press) from the very outbreak of hostilities onwards, as they reacted to the latest harsh treatment of individual conscientious objectors and internationally mounting casualty figures. This was in general contrast to the anti-war sentiments expressed by a proportion of women who expressed their opinions on the war, often formulated by first-hand observation as writers, diarists or reporters, or who volunteered to nurse the wounded and dying troops in the various theatres of war or at home. The thoughts and feelings of those women who chose to express them were most often recorded in book form and published in the second half of the war or in the months and years following the Armistice. The majority of women who had trained as nurses had done so in innocence, out of a sense of duty to their country and a desire to be of use - to grasp a long-denied chance for action and experience in the world of men, a world, as it turned out, now unfamiliar even to the men who engineered and dominated it. It was not then surprising that some women were horrified at 
what they found to exist hidden beneath the rhetoric of newspapers and politicians and were forced to confront their sometimes ill-founded initial motivations for becoming involved in the war at the closest quarters. Some women, however, seemingly needed no public re-examination or questioning of their initial patriotic or idealist motivations, despite perhaps observing hospitals filled with casualties shattered in mind and body.

One such - at least on the surface - was Sarah Macnaughton, who travelled to Antwerp in September 1914 to work in a hospital and who used her subsequent experiences to answer some of the 'women's questions' raised by the war in the final chapter of her book, A Woman's Diary of the War, entitled 'From a Kitchen Window'. Was the transformation of a child into mere 'labelled humanity', to then be passed around on a succession of bloodstained stretchers, 'worth the victory'?, Macnaughton asked. Since women had no voice in the making of the war, a woman sitting by a sick-bed 'when the candles are burning low' would be bound to seek some explanation for the 'horrible idiocy' of the situation and, while recognising that the war had to be fought, wonder why it was that men and nations of reason could not settle their differences in a sober manner. In common with other female commentators and observers, Macnaughton stated that since women produced life from their very bodies, 'the whole idea of the value of life is inherent in them'. Hence the war and its careless destruction of life would be viewed frequently by women as illogical; since women had been told repeatedly that the war was one of steel, powerful engines, oil and petrol (all of them previously associated with men and male occupations) then why was it not possible to remove the human element altogether from the equation of conflict?

Macnaughton then proceeded to reply to her own (and all women's) questions by declaring that the 'pious horror' towards war exhibited by women was 'inadmissible' because the concept of honour was a thing of more intrinsic value than life itself, while the reality of war did not lay solely in the resultant suffering. For example, war could mean greater freedom and opportunity for women within society alongside being a struggle for the same concept on an international scale. Besides, the war had shown an emotionally frustrated Great Britain ('we had far too much energy and not enough to do') what was worthwhile and what was not. Belgium had undergone a 'tremendous re-birth' through its experience of suffering while France had learned a 'noble seriousness'. The British dead and the women who mourned them could be assured of the rightness of the cause and the certainty of a joyful reunion: 'We think that when the last roll is called we shall find them still cheery, still unwavering ... and still - who knows! on active service'.

This was the publicly expressed opinion of Macnaughton (and what she knew her domestic audience expected to read) in a text replete with the initial high emotion of the first few months of the war and thoughts of consolation as the war settled into its unexpectedly lengthy course. However, the private 
Macnaughton expressed markedly different thoughts which were later revealed in her diaries, published in 1919. Such was the difference in tone that Macnaughton's niece (and editor of the diaries) warned that regular readers of her aunt's books would find her latest volume a 'slight surprise' due to an unfamiliar tone that ran throughout the new volume: 'a note of depression and sadness, and perhaps even of criticism'. ${ }^{10}$

From the time that she arrived in Antwerp to do hospital work in September 1914, Macnaughton had found herself surrounded by pain and suffering on an unprecedented scale and unable to console herself with thoughts of 'the Flag' or religion, in an atmosphere 'of bandages and blood'. As time elapsed and she saw more of the war's effects via her work with Dr Hector Martin's Flying Ambulance Corps near Dunkirk and St Malo, she found that her previously firm views on soldiering and warfare were now wavering. 'All my previous ideas of men marching to war have had a touch of heroism, crudely expressed by quick-step and smart uniform', she wrote after a visit to the shattered town of Furnes, 'Today I see tired dusty men, very hungry looking and unshaved, slogging along, silent and tired ... God, what is heroism: It baffles me. ${ }^{11}$ Macnaughton was particularly affected by Furnes, thinking it a tragic place filled with ghosts which seemed to stifle her thoughts to such an extent that she found writing in her notebook an impossibility and was forced to return to the hospital, 'where at least I was with human beings and not ghosts'.

At La Panne in February 1915 she remarked on the 'peculiar brutality' that existed and animated everything within sound of the constant guns. 'Nothing seems to correspond', she wrote in her diary:

Are men really talking and dying in agonies quite close to us ... It is one of the singular things about the war, because one always hears it said that it is deepening people's characters, purifying them, and so on. As far as my experience goes, it has shown me the reverse. ${ }^{12}$

In April 1915 at Boulogne she observed the British and Canadian wounded being brought back from Ypres and placed in the casino, the vast plastered rooms of which echoed constantly with sounds of pain. Macnaughton, confronted with these sights and sounds, caved in to her true feelings:

It isn't right. This damage to human life is horrible ... at last, in a rage, one feels inclined to cry out against the sheer imbecility of it ... Why bring lives into the world and shell them out of it with jagged pieces of iron? ... I am sick with seeing suffering. ${ }^{13}$

She was asking herself the same questions that would appear in 'From a Kitchen Window' later that year, but, unlike the confident author whose readers required that they be given reassurances, the private woman was unable to find a similar level of consolation. She still felt that creativity was stifled by the coarseness of army life; even the songs of the soldiers were 'forced and foolish'. She lamented the lost opportunity for reading and the fact that nobody seemed to look at pictures with the same intensity as before. 'The poetry of life seems to 
be over', she concluded whilst continuing grimly with her work, which in 191516 included the production of four books, a series of thirty-four lectures to munitions workers throughout the British Isles and visits to Stockholm, Petrograd and Tehran, all accomplished 'in the shadow of the death of youth'. Macnaughton, who died exhausted in July 1916, was driven by an ultimate need to champion life, whether in the form of creative energy, the cause of the survival of youth or ministering to those wounded physically or emotionally by war (she did not find this hard: observing an ambulance of wounded civilian children and orphaned babies, Macnaughton commented, 'I think King Herod himself might have been sorry for them'). This was accomplished with a full knowledge and appreciation of a woman's perspective on life and, it followed, the untimely extinguishing of it by the war. 'I suppose women will always try to protect life', she confided to her diary:

because they know what it costs to produce it ... At present women are only repairers, darning socks, cleaning, washing up after men, bringing up reinforcements in the way of fresh life, and patching up wounded men, but some day they must and will have to say [to men], 'The life I produce has as much right to protection as the property you produce and I claim my right to protect it. ${ }^{14}$

Macnaughton was not the only female observer of the war to proclaim a populist view while harbouring inner reservations over the validity of a woman's place in relation to a conflict created by men for men to die in. 'These men fell for their country, in the cause of Democracy, against a cruel and relentless form of militarism', wrote Mrs Alec-Tweedie in her account of her visits to various battlefronts; 'Better, more glorious to do so, than to skulk in corners as pacifists, strikers, Bolsheviks, all of whom are trying to tumble over the very foundations of home and family, national life and real liberty. If a country is worth anything, it is worth fighting for. ${ }^{15}$ Kathleen Burke, who visited the French front as an observer, proudly explained to General Petain how a pre-war political society, the Scottish branch of the National Union of Women's Suffrage Societies, had, 'with that splendid spirit of patriotism which had from the first day of the war animated every man, woman and child of Great Britain', organised itself into the Scottish Women's Hospital movement. ${ }^{16}$

However, even seemingly clear cases of simple, patriotic motivation could be muddied by conscience. The restless journeys for Mrs Alec-Tweedie were prompted by a visit to the grave of her son who had fallen near Loos fighting in the Royal Field Artillery. Although she stated that women and men must play their parts in war (a war which, she admitted, in its modern and mechanised form, could be 'a battlefield of life' and a 'cesspool of false report'), the same was true, she thought, of the search for peace, and she expressed her view, similar to that of Christabel Pankhurst, that the war was a male concept and that women were naturally opposed to war: 'Can any woman ever look upon a battlefield and not feel her very soul revolting against war, fiercely insisting that wars must cease, that she will not bear sons to grow to men and be butchered. ${ }^{17}$ 
In addition, Kathleen Burke had also pointed out to Petain that the formation of the Women's Hospitals out of the Suffrage movement, 'was no longer a question of politics, but simply a case of serving humanity ... a time for organised effort on the part of all women for the benefit of the human race and the alleviation of suffering..$^{18}$

The alleviation of suffering, then, was recognised by women themselves as a prime factor in the decision to take up nursing. In many cases, patriotism, as Nurse Edith Cavell had declared, was not enough. Working at a distance from all the inflated rhetoric of the Home Front popular press could provide a different perspective on one's home country, as in the case of Dorothy Cator, who nursed in a French military hospital at the start of the war and commented that, 'We are still wonderfully frog-like in our point of view of anything that is not English. When we get to the top of the hill, though the whole world is lying at our feet, we keep our eyes thrown back on our own land.' Cator hoped that a positive result of 'this awful and costly offering of strong, beautiful life' would be a lessening of Britain's insularity and innate prejudices. 'It seems strange', she lamented:

that we should be found so lacking in sympathy, but in our ignorance it is so. We have forgotten what we stand for ... England has been living on its reputation and has been much to blame, but may it now be wise enough to see its own faults, generous enough to own them, and strong enough to correct them. ${ }^{19}$

A wider perspective on the war and its causes was also experienced by another woman at the front, Olive Dent, who, on volunteering, was accepted for foreign service in the summer of 1915 and was immediately sent to France. When war had been declared, Dent had found the very notion of armed conflict to be an 'unreality' and something that was usually confined to disputes between far-flung nation states. Once in France and able to observe the lines of gravestones at Wimereux, she found herself made fully aware of the youth and beauty that had been consumed by the conflict and the lines of smoothed stones came to represent 'man turned to destruction', while each individual stone called to mind 'a gap in some home across those dark waters'. ${ }^{20}$ She found herself so affected by the reality that confronted her that she felt the need to record and communicate her experiences to a wider public - hence her memoir, AVAD in France, which was published in 1917.

Many of the memoirs and stories constructed by women from their experiences and feelings relating to the Great War did not appear for some years after 1918, despite the intensity of feeling involved. This was probably due to the slow pace of the alteration of the circumstances of women in the post-war period in terms of financial, creative and emotional independence from men, despite their newly-acquired political freedom (i.e. through the vote given to householders over thirty). The publication of the experiences of nurses and observers of the battlefields during the war had been made possible by the hunger of a reading public eager for descriptions of the circumstances in which 
their loved ones were living and dying, and a recognition of this appetite by financially-aware publishers. A further contribution to swift publication during the war was the usual tone of the material, which was to a large extent always ready to extol the glorious cause and worthwhile sacrifices, often in order to justify the reality of the situation in the mind of the author; a reality, which if it had been fully exposed, would probably have prevented the work's appearance before a wide wartime public carefully shielded from many of the facts of the front by the popular press.

However, as in the case of works of reportage and literature by men, ${ }^{21}$ some of a critical nature did appear early on, though most, again as in the case of material from a masculine perspective, appeared steadily over the next decade and into the 1930s and beyond. One such was that attributed to an anonymous woman of the WAAC (Women's Army Auxiliary Corps) which appeared in 1930 and, like that of Olive Dent, recalled an acute alteration of perspective on the war due to direct contact with it. 'The war turned one topsy-turvy, altered one's outlook on life. I felt I could never be pre-war again', she wrote. The former WAAC officer declared that she did not care to dwell on the memories of her war experience that the writing of the book had thrown up, even after such a considerable amount of time had elapsed since the original events had occurred. She found herself still appalled by the number of men's lives cut short, physically blighted or mentally 'deprived of their reason', and she wondered how women came through the same conflict 'without ourselves becoming insane'. Her conclusion was that:

we all tried not to think - we had little time for thinking except when off duty, and then we were so exhausted that most of us fell asleep. Yet there were nights when I, and I expect others, cried ourselves to sleep at the inhumanity and brutality of it all. ${ }^{22}$

Nocturnal doubts also plagued those who had not even come into contact with the full reality of the war zone and reveal that it was not always a straightforward decision for a woman to volunteer to go to the front. May Sinclair, the author of such fictional propaganda as Tasker Jevons (1916) and The Tree of Heaven (1917), recorded the 'frightful anticipation' of the weeks prior to her departure for the continent in order to work with the Motor Field Ambulance Corps in her book, Journal of Impressions in Belgium, an anticipation based on both the excitement of coming adventure and extreme fear of the unknown: 'going to bed night after night, drugged with horror, black horror that creeps like poison through your nerves'. She recorded that the mind would eventually forget the ordeal to come under the calming drug of sleep but when one woke the lucid brain would immediately construct yet more mental images of the war, 'a dozen war pictures a minute like a ghastly cinema show, till horror becomes terror'. ${ }^{23}$ Whether the reality of war matched or exceeded the terror of anticipation, it was difficult to communicate impressions of horror in letters to those at home who expected reassurances to assuage their own fears. Hence 
truer feelings were often relegated to private diaries, and it was these impressions that were often used as the basis of a later account of the war, whether as fact or fiction.

The actress, journalist and writer Evadne Price made use of her diaries recounting the lives of the volunteer ambulance drivers in her semi-autobiographical novel, Not So Quiet-Stepdanghters of War, which she published under a pseudonym - Helen Zenna Smith. One bitter passage describes, in an almost stream-of-consciousness manner, the denial of truth involved in writing to family at home about events at the front and the uselessness of even attempting to convey the terrible truth; If one told the truth, namely:

that all the ideals and beliefs that you ever had have crashed about your gun-deafened ears - that you don't believe in God or them or the infallibility of England or anything but bloody war and foul smells and smutty stories and smoke and bombs and lice and filth and noise, noise, noise - that you live in a world of cold sick fear, a dirty world of darkness and despair - that you want to crawl ignominiously home from these painful writhing things that once were men, these chattered, tortured faces that dumbly demand what it's all about in Christ's name - that you want to find somewhere where life is quiet and beautiful and lovely as it was before the world turned khaki and blood-coloured - that you want to creep into a refuge where there is love instead of hate ... Tell them these things; and they will reply on pale mauve speckle-edged paper calling you a silly hysterical little girl - 'You always were inclined to exaggerate, darling. ${ }^{24}$

Not So Quiet was not published until 1930 and was awarded the Prix Severigne in France as the novel 'most calculated to promote international peace'. The narrative of the four central characters was continued in four further volumes during which the war-blighted life of the narrator became worse and worse, her fear during the first volume of the permanence of mental images of maimed men with burning eyes confirmed:

I fear them, these silent men, for I am afraid they will stay with me all my life, shutting out beauty till the day I die. And not only do I fear them, I hate them. I hate these maimed men who will not let me sleep ... Oh the beauty of men who are whole and sane. Shall I ever know a lover who is young and strong and untouched by war, who has not gazed upon what I have gazed upon? Shall I ever know a lover in whose eyes reflect my image without the shadow of war rising between us?25

Price articulated the feeling that women, too, could have their lives blighted by the war in a personal sense, if not in a professional one, as they, 'smilingly stumbled' from suburban chintz-covered drawing-rooms into an unforseen hell. Price's character posed the question many women who saw the truth of the war found themselves asking; 'What is to happen to women like me when this war ends?' Price's narrator declares that she is twenty-one and yet knows nothing of life but death - as well as fear, blood and the false sentimentality of patriotism. She also realises, after a period of leave, that she has become accustomed to being a machine, 'Outwardly I am Smithy, assistant cook [she has by this point 
given up VAD work for a lower domestic position in the WAAC]; inwardly I am nothing. I have no feelings that are not physical. ${ }^{.26}$ Though sunk in mental atrophy herself, she fears for the following generation, raised in a 'blood-andhate atmosphere' and fears that, as a result, they will be callous, predatory and 'cruelly analytical'. Price's narrator has become so mentally numbed following her own experiences that her reaction to the news that her fiancé has possibly been killed in action is very muted. Replete with fatalism, she rationalises that if soldiers such as her fiancé are not killed by the gas, guns, and grenades, they are simply patched up and sent back to eventual death: 'It is only a matter of time.'

Evadne Price saw the ordinary soldiers as innocents, caught up in a wider scheme over which they had no control. A similar view was taken by Mary Borden in her fictionalised account of her work as an American VAD in Flanders, the Somme and Champagne in which she highlighted the irony of having to return to the front over and over again. Like Smith, she saw the situation as a larger plan from which the ordinary individual had no escape. 'Listen', she wrote with matching irony:

you can hear how well it works. There is the sound of the cannon and the sound of the ambulances bringing the wounded and the sound of the tramp of strong men going along the road to fill the empty places. Do you hear? Do you understand? It is all arranged as it should be. ${ }^{27}$

Borden likened the war to a second Flood of biblical proportions and the wounded as 'wrecked men', survivors from a former world. Like the anonymous WAAC officer and May Sinclair, Borden found herself kept awake at night by the 'familiar, muttering' noises of the war; the 'feeble, mewing, whimpering voice of Life' and the 'loud triumphant guttural shouts of Pain plying her trade in the hut next to me'. ${ }^{28}$

Borden's most arresting image was her impression of a French territorial regiment en route from the trenches to a local town. These survivors were also 'wrecked men' in that the war had warped and altered them; from a distance they looked deformed and hunchbacked as they moved laboriously through the dust and everything about them created an impression of age and weariness. 'They had not quite the colour nor the shape of men. The war had spread over them its own colour ... Fatigue and suffering and dirt had soaked through them and had made them this colour.' All were deformed in the same way by the same war:

The same machine had twisted and bent them all ... There was no elasticity in them, nor any enthusiasm, nor any passion ... Suffering was a part of their rations. They were acclimatised to misery. Death was a part of the equipment they carried always with them.

Borden likened them to trees which had been uprooted from their earthy settings, leaving gaping holes, and carted away to 'the bleak desert of death' where, instead of growing freely, they were now chained and fastened to the earth, 
pulled down with their burdens of suffering: 'as dark weight scraping the road', in startling contrast to a plane passing overhead above them. ${ }^{29}$

Borden's fictionalised account was not published until 1929, the same year in which Maude Onions' A Woman at War appeared, a factual account of her time as an army signaller in France which displayed a similar insight and compassion regarding the plight of the ordinary soldier, especially in contrast with the bland tone of the official bulletins. 'It was only when the mask was drawn aside for a moment that one realised how the seeming futility and endlessness of the war was eating into the souls of the men'. ${ }^{30}$ Onions had been surprised by the level of the men's disillusionment she encountered when she arrived in France in 1917 and, like Borden, was painfully made aware of the endless stream of wounded which arrived at all hours of the day and night with 'ceaseless monotony' and was also concerned, like Evadne Price, about the effect of the war upon the following generation as she observed French children travelling daily to school through scenes of utter desolation and ruin.

Onions spent time talking to those with whom her work brought her into contact, and she recorded the uncertainty of a soldier who found himself afraid of returning to civilian life, explaining that, 'my brains you see have run to seed', as well as the puzzlement of a gunner who found it difficult to connect the lamb's wool used for cleaning gun muzzles - which reminded him of his former job of sheep-rearing - and the purpose of the weapon itself, it being hard for him to comprehend the transition he was forced to undergo from the procurement of life to the taking of it. Onions also recorded her conversation with a man who forced her to admit to him that she thought the war to be wrong and then challenged her as to her part in it, stating that to meet wrong with wrong would only aggravate the larger, inherent evil of the war's progression. He then revealed himself to be a conscientious objector and pointed to the paradox that, while each believing the war to be wrong, both of them were in France involved in war-work of some sort. Onions came to the realisation that the separate identities and personal freedoms of both men and women could be adversely affected by the war's infringement upon the course of ordinary life. As she stated in A Woman at War, 'From the moment of enlistment in the "War for Freedom", freedom for the individual ceased to exist. The separate identity of men and women became submerged. ${ }^{31}$

This recognition of the submergence of personal identity - already identified as part of the male experience - was most often applied to those who had actually experienced battle: from Mary Borden's weary French regiment to the wounded survivors observed by the women who cared for them. One nurse likened her patients to ghosts as they all filed into the mess in coloured dressing-gowns, 'gentleman, tinker, and tailor; each having shuffled home from death; each having known his life rock on its base'. All had become 'creatures of habit'. ${ }^{32}$ The nurse in question was Enid Bagnold whose memoir of her time as a VAD nurse was published in 1918 as Diary Without Dates. 
At the outbreak of war, Bagnold volunteered for nursing work and found herself at the Royal Herbert Hospital, Woolwich, where she found herself greatly affected by the wounded men's attitudes towards life as a result of their involvement in the war. She found they had become, 'careless of life ... of all the whims and personalities and desires that go to make up existence', and to her they seemed 'new-born' from the fire of their experience, their personalities wiped clean, and child-like in their unquestioning acceptance of each other and faith in the nurses. She also became aware, like Mary Borden, to what extent the men had been wrenched from their former existences ('Watchmakers, jewellers, station-masters, dress-designers, actors, travellers in underwear, bankclerks...') in order to be made into soldiers. 'To what a point their lives are suspended', she mused, while considering their motivations for allowing their lives to be altered to such an extent, particularly when one of her anti-war friends visited the hospital and asked a former dairyman why he fought simply because someone told him to.

Bagnold tried to see the situation from a personal, masculine point of view:

It isn't so simple as that, is it, dairyman? It isn't even a question of the immense, vague machinery behind the sergeant, but just the sergeant himself: it isn't a question of generals or politicians; of great wrongs or fierce beliefs ... but of the bugle which calls you in the morning and the bugle which puts you to bed at night. ${ }^{33}$

She acknowledged that the male, military experience of the war was something in which she, as a woman, could not share and therefore could not fully comprehend: 'I - a woman and therefore of the old, burnt-out world', as she classified herself. Bagnold found herself almost frustrated in her inability to share in the life-altering experience of the soldier, particularly as, 'It must happen to the men in France that, living so near the edge of death, they are more aware of life than we are.' She retained the faint hope that, 'When they come back, when the post-war days set in, will they keep that vision, letting it play on life ... or must it fade? ${ }^{34}$

Bagnold later joined the First Aid Nursing Yeomanry and served in France as an occasional driver as well as undertaking further nursing, and these experiences formed the basis for her novel The Happy Foreigner (1920). When Diary Without Dates was published in 1918, she was immediately sacked by the Matron as she arrived for work, although she derived satisfaction from a sympathetic article in the Daily Mail (linked to a debate over alleged unfeeling routine in a Rouen hospital) and critic Desmond MacCarthy's typically descriptive appreciation of her courageous stance as a 'Lionetta'.

Enid Bagnold was to build on the fame thrust upon her by the popularity of Dairy Without Dates with her many plays and novels whereas the other most celebrated nurse-turned-author of the Great War, Vera Brittain, achieved her (possibly greater) fame solely through her memoir of her war years, published in 1933 - unlike Bagnold's volume, which appeared in the final months of the war. We are now able to study Brittain's actual diaries and letters of the war 
period, and they reveal that her pacifism was somewhat slow to reach maturity, as recognised by Yvonne A. Bennett, who specified that Brittain's anti-war feeling, 'from its inception, was rationally and pragmatically inspired' ${ }^{35}$ At first, the war gave a 'spurious simplicity' to emotional life, and Brittain, who (like Bagnold) 'longed to live at an intense level', responded with a conventional upper-middle-class patriotism; her 'great fear' in the first few days of August 1914 was that Great Britain's 'bungling' government would declare its neutrality and refuse to assist France, and hence be guilty of 'the grossest treachery'. She urged her brother Edward to volunteer and began to knit garments for the soldiers ('the only work it seems possible as yet for women to do').

However, by 1915 the 'shallow patriotic tone' vanishes from her diaries and letters as she became more disillusioned with the reasons behind the fighting. ${ }^{36}$ Eventually, through a combination of personal loss and observation of the war's effect on individuals during her time as a nurse, she came to resemble Evadne Price's narrator in that her coming of age was marred by a too-full knowledge of death. 'O glorious time of youth indeed!', she lamented in her diary in April 1915:

This is the part of my life when I ought to be living every moment of the full, tasting the sweetness of every joy, full of love and life and aspiration and hope, exulting in my own existence. Instead, I can only think how weary are the heavy hours, wonder how I can get through their aching suspense, wonder when they will end - and how. Ah! Those who are old and think this was so terrible do not know what it means to us who are young. They at least have had their joy, have it now to think of and look back on; for us the chief part of our lives, the part which makes all the rest worthwhile, has either never dawned, or else we have for a moment seen what is possible only to have it snatched from your eyes. ${ }^{37}$

While she continued with her nursing, her emotions became deadened. As she wrote in the winter of 1916 after the death of her fiancé, 'In the utter blackness of my soul I seem to be touching the very depths of that dull lampless anguish which we call despair ... I am crushed - altogether crushed, by life - I have no power of resistance left, no courage - not even any desire for courage'. ${ }^{38}$

Every hope had been blighted. She had felt great personal satisfaction in passing the Oxford Senior Exam in Latin, French, Arithmetic and Algebra in August 1914, as Oxford to her meant, 'a breaking down of oppressive boundaries and a step towards freedom and liberty of thought, work and endeavour'. Instead, she found her hopes and happiness 'transformed by the same grey despondent mist that alters everything now ... This is no longer a time to see how much enjoyment one can get out of life, but to see how much courage and strength one can give to it.' There were now only two possible options - to act and to endure. ${ }^{39}$ She turned to nursing partly so as to involve herself in hard manual labour and so perhaps banish constant thoughts of the danger of her fiancé, Roland Leighton, especially after the casualty lists were published after the battle of Neuve Chapelle in March 1915. She realised with regret that 'my 
sort of work' (i.e. academic study) was much less easy or needed in an atmosphere obsessed with military victory and, 'when so much of intellectual life seems at a standstill and the war cry drowns the purer voices of the upper air'. However, she vowed not to shirk the intellectual life ('the work for which I was made') simply because the nations had temporarily forgotten that the intellectual life 'reigns supreme above the strife of nations'. ${ }^{40}$

As a woman, Brittain, like Bagnold, felt herself to be an outsider - unable to experience, share and perhaps understand the dangers faced by her brother and Leighton; in March 1915, at the same time that she was deciding to become a nurse, Brittain described herself, as 'a weak imperfect being, whose only interest in the war was through individuals concerned in it'. Her decision to nurse was also based on a desire to experience more of the war in order that she might satisfy her growing doubts concerning the motivations behind it and the truth of the horrors of the actual fighting, as expressed by Leighton in his letters to her. By the time Brittain commenced her nursing at the Devonshire Hospital in June 1915, her compassion had already started to reach out beyond the abstract and embrace others; news came that a former friend had been killed in the Dardenelles and 'a dull, agonising ache' began. While listening to an organ recital at New College Chapel, she mused upon her likely reaction to a British victory and concluded that she would not be one of those taking a happy part in the triumph; 'Even if I do not lose directly my heart will be too full of what others have lost'.

The practical observations of nursing brought home to her, as in the case of Maude Onions and the conscientious objector, the paradoxical element to the war. After tending to a badly wounded prisoner of war, she found herself 'disturbed' to realise that, 'Wasn't it somehow odd that I, in Etaples, should be trying to save the life of a man whom my brother up at Ypres had perhaps done his best to kill? And didn't that argue the existence of some fundamental absurdity in the whole tragic situation. ${ }^{41}$ Also, Leighton had told her before he even went to the front that he had no personal animosity for the enemy and wished he were back at Oxford amongst his books. His reasons for enlisting had sprung from very individualistic motives: an attempt to live up to his own expectations of himself coupled to an 'indefinite pursuit of heroism in the abstract'. He later confirmed in a letter to her that he had found no glory in trench warfare, only endless waiting and the taking of 'petty advantages' and though people talked of ideals, 'it is all for nothing - for an empty name'. ${ }^{42}$

Leighton was killed in December 1915, at which point Brittain was nursing at the 1st London General Hospital, Camberwell. She later nursed both British and German wounded in France in 1917, and it was then that her pacifism and inspiration for her anti-war writings of the 1920's and 30's came to full fruition as she sensed the seeming indifference of the belligerent governments towards the mounting numbers of dead and injured of both sides that she came into contact with. She likened the war to a snowball gathering volume as it rolled: 
Every day seems to take us further from the end. Every month introduces some new and complicating element which further involves all the elements already there. It is too gigantic for the mind to grasp. And through everything, involving things still more, run everyone's personal interests and loves and despairs, most terrible of all. ${ }^{43}$

'The only way to see war is from a hospital'. Such was the view of Mabel Dearmer who volunteered to nurse in Serbia in March 1915. She, like Brittain and other women observing the male world of military might 'from the wings', recognised the inherent paradox of the situation. 'War is the devil's own', she wrote to her friend Stephen Gwynn, 'When I see these wounded here ... I don't see you and Geoff and Chris [her sons, both serving] hurt, but I see all the men that you and Geoff and Chris are going to hurt as these men are hurt - and that is the unbearable thing.' She also was aware of the roles that both men and women were forced to play in a country at war. 'We do live in odd times', she wrote while ill herself in hospital, 'the men go out to kill each other in order to settle some question, and the women - well, if the women can't be ministering angels and brave dangers, they just become horrid little cats and break rules and squabble'. ${ }^{44}$ When Gwynn wrote to her that 'the gilt is off war' after the sinking of the Lusitania, she replied with astonishment, 'But was there ever any real gilt on war?' She stated that she could be no more angry with the men of another nation for robbing her of her sons than with an earthquake: 'It is all ignorance and folly' she concluded.

Like Vera Brittain and Dorothy Cator, Dearmer became disenchanted with what she referred to as 'this madness of Nationality, this false patriotism' that she everywhere observed while the Serbians were dying around her ('they are human beings wasted'). She also deplored the limited choice open to the individual in a nation geared to war, noting that 'today it is Christ or Kitchener'. To her, the folly of the situation was easy to identify: 'As long as men grab land and think it noble to die for their own bit there will be wars. As though a nation depended on its land! It depends on its spirit and ideals ... This war will not bring peace. ${ }^{45}$ Dearmer died of typhoid in July 1915, and her younger son was killed at Suvla Bay later that year. In his memoir of her, which was published by Macmillan with her letters to him in the year of her death, Gwynn commented that she had left her career as a book illustrator and author of children's plays for the harsh battlegrounds of Serbia, not because she was an Englishwoman or simply followed her husband, but 'because she was a woman'. He recalled that her motivations, 'were born of her own thought, not impressed from outside', and that the war and the resultant situations in which she found herself had produced in her a 'disturbance' far greater than in others: 'For her, no harmony was possible between natural life and these unnatural times. ${ }^{46}$

Dearmer had volunteered to go to Serbia after sitting through a farewell service at St Martin's in the Field in London which had been arranged by her husband, Percy Dearmer (chaplain to the British units in Serbia), under the auspices of the Church League for Women's Suffrage. The service was a farewell 
for a unit about to leave for Serbia and organised by Mabel St Clair Stobart who, when approached by an inspired and eager Dearmer at the end of the service, immediately informed her that Dearmer would have to leave her long earrings and fur coat at home if she were to be accepted for a role in the unit as a hospital orderly. Stobart had been approached after the Kingway Hall meeting of women's organisations on 4 August 1914 to do something practical on behalf of women and she had responded by establishing an office and headquarters for the Women's National Service League in St James Street the following day. She also found time to send a letter to the Daily News complaining of the double standards of morality imposed by the war between women and men as well as between individuals and nations.

Stobart was the natural choice to surmount the practical difficulties of organising some form of women's hospital unit that would work abroad. She was already nationally celebrated for her role in the establishment of the Women's Sick and Wounded Convoy Corps, a medical unit staffed entirely by women, including the doctors. During the first Balkan War in 1912, she and the corps had travelled to Bulgaria against the advice of the British Red Cross Society and had established a hospital at Kirk-Kilisse, the existence of which marked the first time that female doctors had worked at a front-line hospital during wartime. By 1914, Stobart was fifty years old and was putting the finishing touches to her memoirs of her experience of the Balkan conflict - an experience that had convinced her of the futility of war.

Stobart later described the establishment of the Hospital Units (the Women's Imperial Service Hospital) in the first few weeks of the Great War as, 'a protest, passionate, sane, practical, of the civilised against the barbaric; of the spiritual against the material'. ${ }^{47}$ Between the establishment of her office in St James Street in the first few days of war and her meeting with Mabel Dearmer on the eve of her departure for Serbia in April 1915, Stobart led an ambulance unit on behalf of the St John's Ambulance association to Brussels and was nearly shot as a spy as the Germans overran the city. She then went to Antwerp where the hospital was in the German line of fire of an ammunition dump and hence at serious risk of bombardment itself. Stobart and her staff were forced to leave with the wounded and were the last to escape the ruined city by way of a hastilyconstructed boat bridge before that too was destroyed. She then accepted an invitation from the French Red Cross to set up a hospital at Cherbourg and hence was chosen by the authorities to lead the British hospital unit to Serbia in the spring of 1915.

Stobart's motivations behind her immense practical achievements during the war were clearly defined and set out in her description of her time in Serbia, $A$ Flaming Sword in Serbia and Elsewhere, which was published in 1916. In the Preface, she described the stark choice facing humankind: evolution or retrogression. To her, militarism was a retrograde step which would bring the progress of civilisation to a halt. ${ }^{48}$ 'The sign-post to devolution is militarism', she declared, 
adding, 'and I believe that militarism can only be destroyed with the help of a woman' ${ }^{49}$ To women, Stobart declared, life was not a game of chance but an 'individual charge' (and hence their dislike of militarism was 'an instinct') and, since primitive woman had always defended 'individual concrete life' both before and after birth, modern woman was charged on a larger scale with defending 'the abstract life of humankind'. To Stobart, a male disapproval of militarism was based on sentiment or expedience and not on instinct and was, therefore, not forceful enough to have the required effect. Again in common with other female observers of the war, Stobart felt the paradox of the conflict keenly: 'Society holds that no motive justifies murder when it is retail, and concerns individuals; but when that murder is wholesale, and concerns nations, no motive justifies abstention from the murder-fields'. She also, like many other women, worried for the sensibilities of the coming generation in that:

Civilisation, as we were taught, meant the progress of the human race in ideals, spiritual and moral. Civilisation, as our children are being taught, means progress in the invention of machines for destroying life - the one thing on earth that can't be made by machines.

Modern warfare was 'a business for butchers' and represented a 'negation of civilisation', especially for women: 'Of what use the care and labour spent in science, art, culture, education, it, at the command of militarism, these and their votaries are to be periodically blotted out. ${ }^{50}$ Stobart saw how the war reached out to affect those who would or should have no part in it:

War is not merely an encounter between rival armies of man. War is, in these days, an encounter between equipped armies and unequipped women and children, with results that are bestial and humiliating; between equipped armies and unequipped civilisation with results that are destructive of civilisation. ${ }^{51}$

As Claire Tylee has pointed out in her The Great War and Women's Consciousness, Stobart felt that society needed the more forceful promotion of 'womanly' values in order to, 'channel the courage required by militarism away from the battlefield and into moral, social and spiritual purposes'. ${ }^{52}$ In this, Stobart reflected the concepts expressed by Bertrand Russell (Principles of Social Reconstruction and Flaming Sword both appeared in 1916) surrounding the channelling of the creative and destructive energies of society. Stobart believed that society needed to allow a fuller recognition of the nurturing instincts of women. This proposition was not simply offered from an exclusively feminist perspective, but would benefit both genders (and thus all of society, international as well as national) by promoting peaceful pursuits and thus lessening the chances of future war.

By the beginning of May 1915, Stobart, propelled by her need to minister to the wounds of militarism, reached Kragujevac in Serbia. The 3rd Serbian Relief Fund Unit comprised of fifty staff, including seven women doctors (this number later increased to fourteen). Upon her arrival, Stobart requested and was 
granted forty more doctors and nurses from England in order to establish a system of roadside dispensaries to combat outbreaks of typhoid amongst the local populations. Each dispensary was soon dealing with a hundred people each day, including home visits using an ox-wagon as a makeshift ambulance. During the first few months in Serbia, approximately twenty-two thousand people received help from these dispensaries. In October 1915, Bulgaria attacked Serbia, and Stobart was asked to form a 'flying field hospital' at the front for the Serbian army which would include persons from the original unit and Serbian soldiers as ambulancemen. Stobart, with her earlier Bulgarian experience behind her, here came into her own as the Serbian-English Field Hospital became caught up in the Serbian retreat and was forced to abandon the motor ambulance and hospital equipment at the foot of the Montenegrin mountains. Stobart, who had - uniquely - been appointed a commander with the rank of Major in the Serbian army, led her column on foot through the often trackless mountains in mid-winter, during which an estimated ten thousand Serbian soldiers and civilians perished (with over four hundred thousand taking part in the actual retreat).

Stobart refused to abandon her Field Hospital and re-join the original Relief Fund Unit; in the end, only five of the original staff remained with her as she became the only commander to reach Scutari in Albania (after three months and eight hundred miles) without a single loss of life. Once back in Britain by way of Brindisi and Rome, she was reprimanded by the Serbian Relief Fund Committee for exceeding her instructions. Undeterred, she then undertook a lecture tour of America, initially backed by the Ministry of Information, which she angered by then insisting on financing herself. She then also donated all profits to the Serbian Red Cross. On her return to Britain, her request for another appointment was ignored, and she never heard from the authorities again. Stobart was left to write her memoirs - and to mourn her son, who died in the influenza epidemic of 1918.

In Women of the War, which appeared in 1917 and included an introduction by former Prime Minister H.H. Asquith, Barbara McLaren described Stobart thus:

No woman has seen the war at closer quarters and in more varied fields of action than Mrs. St. Clair Stobart and no one has worked harder to help the sick and wounded ... Everywhere she has sought and found her opportunity to bear her part in the actual campaign - a part such as no woman has ever taken before. ${ }^{53}$

This description was apt because it reflected Stobart's intentions and beliefs as to the role of women during the war. 'The co-operation of women in warfare is essential for the future abolition of war; essential, that is, for the retrieval of civilisation', Stobart wrote, voicing the frustrations of Enid Bagnold and Vera Brittain amongst others. In order to promote the cause of humanity, the cause of war had to be suppressed and this could not be done by men alone, since the society which had failed to prevent the present war had been dominated by 
men. The spiritual power of women had to be combined with the physical force of men if humankind were ever to reach the 'Tree of Life'. In order to facilitate this co-operation of women in warfare, it followed that it was 'good that Woman shall put aside her qualms, and go forth and see for herself the dangers that threaten life ... that Woman shall record, as Woman, and not as neuter, the things which she has felt and seen, during the experience of Militarism at first hand' ${ }^{54}$ Participation in the war from a nursing or reporting capacity would give women a voice to raise against conflict. 'Until woman had obtained some experience of war, she could only express sentiments concerning war; but now she is at liberty to give opinions as to the meaning of war. ${ }^{55}$

In her analysis of Britain under the war, Britain Holds On 1917-1918, the cultural analyst Caroline Playne examined the effect on daily life on the Home Front, where the war, 'filled up all the already full places of life', and the effect of the 'crushing blows' dealt by the conflict upon the spheres of art and literature. 'In every sense', she concluded, 'the war took the gilt off life, even off literature. ${ }^{56}$ She thought the war too vast an event from which to harness themes for works of literature other than war stories. The complexities of character and adventure (as well as life itself) had 'lost their savour'. Compared to the experience of serving in the war, everything else seemed subsequently small and insignificant while for most others, 'dullness has deadened life'. But was this view perhaps not placing enough faith in the abilities of the artist to catch at least one of the 'myriad faces' of the war? This was the opinion of another female commentator on the conflict, the novelist Storm Jameson, who wrote in her autobiography:

Do we ... think of the war as an event, an experience too singular or too vast to be tampered with by the conscious artist? Or is it that we half misprize the novelist as a person too cheaply bought off by easy emotions, too facile, not fit to be trusted to handle an experience of this magnitude?

Although she herself thought that no war novel had matched the three or four best personal records of the war, Jameson took to task critics who viewed a war novel as naturally inferior to a 'truthful' memoir: 'We anxiously assure one another that the George Sherston of one book is Mr. Siegfried Sassoon' ${ }^{57}$ (alluding to Sassoon's fictional counterpart). The waters of analysis were muddied further by certain memoirs/novels in which an almost deliberately thin line was placed between fact and fiction, as in the accounts of Helen Zenna Smith/ Evadne Price, Mary Borden and others. In addition, it was rare indeed to find a woman's account, fictional or otherwise, of events surrounding individual humanistic anti-war attitudes that was far removed from the 'traditional' scenes of horror and pity of trench and hospital. One such, however, was penned by a woman, Rose Allatini, under the pseudonym A.T. Fitzroy.

Allatini's novel, Despised and Rejected, traced the development of the antiwar views and actions of the main character, Dennis, a homosexual composer, 
and those of his like-minded associates, as set against certain events, such as the outbreak of war and the introduction of conscription, as well as the hostile views of both his family and the outside world. During the first few months of the conflict, other characters, such as Lance-Corporal Griggs, are prepared to be tolerant of Dennis' lack of enthusiasm to volunteer which they put down to artistic temperament. Gradually Dennis faces increased criticism as he steadfastly refuses to attest under the Derby Scheme. When the patriotic Mrs Ryan takes him to task over his civilian clothes complaining, 'I should like to know where the war would be if everyone thought like that!', Dennis counters, 'Presumably there would be no war at all. ${ }^{58}$ During a discussion about the merits of music (Dennis' friend Crispin has forsaken military life in order to oppose those in authority who would ban German composers from British concert halls), the character of Henriette declares, 'Who thinks - who has the heart to think of music now? For me, if I were a man, there would be but one music thrilling my soul: the roar of cannons' ${ }^{59}$ while Lily Hallard, in her VAD uniform, tells Dennis that the 'proper spirit' should be contained in the desire to get to the front as soon as possible - like Tom Sanderson, who effects a transfer from a cavalry regiment due to lack of action. When Dennis argues that the individual intellect and soul demand satisfaction that the course taken by an individual is for the greater good, Lily declares, 'A fat lot most of our boys think of "intellect and soul"! They just go and do their bit, and don't talk about it. ${ }^{90}$ One of Dennis' severest critics is his father who tends to the view that, 'A little blood-letting won't do the nation any harm', while he regards man as a 'fighting animal' and thinks it 'unnatural' for a man, especially his own son, to have 'no fight in him'. ${ }^{61}$ Dennis and his friends represent the 'unnatural' antiwar stances that Allatini wished to plead a case for and that she herself felt and observed in others.

Allatini's leading character is at odds with all the swirl and bustle of wartime life around him: 'The thought of war inspired in him none of those feelings with which convention decreed that every true Briton should be inspired at times like these. ${ }^{62}$ Dennis recognises and deplores what he regards as the general pretence that the war is a game, 'which every Englishman should be proud to be playing', and resolves not to 'give himself up to the machinery of nations trying to prove which could stand the most blood-letting; machinery that organised the murder of individuals by individuals who had no personal quarrel with each other' ${ }^{63}$ Dennis sets the picture of the nations of Europe locked in their 'death-grapple of hatred' against one of the continent in which the rivers flow calmly onwards, 'oblivious of all artificial frontiers, oblivious if it was French or German or British or American blood that reddened them' ${ }^{64} \mathrm{He}$ resolves to translate the voices of the nations into his music: 'He would make himself the medium through which their individuality, their thoughts, their dreams, their yearnings should be expressed. ${ }^{65}$ Individuality drowned by the war would re-surface within his music. His symphony would transcend man- 
made frontiers and claim kinship with all fellow human beings; it would be, 'as international as art itself'.

Dennis struggles to be true to his nature and instincts in attempting to understand the conflict and its effects from an overall perspective. He describes himself as a 'humanitarian' before his Military Tribunal and when his father challenges his views as unnatural, he pleads his case, replying:

You'll allow a man to conquer nature with his ships and his railways - you'll allow him to widen as much as possible the gulf that separates him from the beast; but when it comes to rooting out the war-instinct - No! He can't overcome that. Why should he? It's always been there, always will be. In fact, you're rather proud of it: it's part of a gentleman's equipment. You want progress and the conquest of natural difficulties in every possible direction and yet you won't admit that a man can conquer himself. You're shouted down as 'unnatural' if you as much as speak of overcoming an instinct that is nothing but a hindrance to civilisation and progress. ${ }^{66}$

Despite his appeal to the tribunal, Dennis is sentenced to non-combatant service and, as he waits to be called up, finds his creative impulses now focused on a symphonic poem which he at first perceives as full of dissonance and counter-rhythms battling to be heard. However, he then recognises that this is a truer picture of the war and that each conflicting noise must be left to make up the whole. 'Each must have its place in the scheme, for each stood for one of the innumerable beliefs and reasons, ideas and madnesses that had led the people into war. ${ }^{97}$ Thus his art can reflect the truth of the reality around him and could act as a conduit for his pacifist and humanistic emotions as he blends all the clamouring voices into one, 'showing their fundamental unity, converting strife and turmoil and the sorrows of all nations into the transcendent harmony of peace'. ${ }^{68}$

In this desire, he is supported by his friend Neil Barnaby, a fellow artist, who laments the wastage of art and intellect that the war has facilitated, stating that:

There are thousands of men being forced to fight, who are physically and mentally unfit to be of the least use in battle, but whose brains might have given us scientific inventions that would have benefited humanity, works of art, books, music ... No, they won't let them stop at home and do what they can do, but must send them out to do incompetently things against which their whole nature rises in revolt. From the general utility standpoint: in which capacity is the artist of more value to the nation? As a creator of a work that may live, or as a mass of shattered nerves, totally incapable either of fulfilling the requirements of the army or of carrying out his own ideas? ${ }^{69}$

He deplores the treatment meted out to conscientious objectors as 'wilful murder of brains that were fine, sensitive instruments which might have brought some lasting beauty, some lasting wonder into the world', and later concludes, 'From every possible point of view, whether from religion art, socialism or 
humanity, war is a disgrace to any civilised nation. ${ }^{970}$ Barnaby supports Dennis' need to translate his feeling on the war and his hopes for peace into his music, despite all hostile opinion. Artists have a duty to their art, despite contrary circumstances; as Barnaby urges, 'Let's at least preserve art from the general wreckage. ${ }^{71}$

The character of Alan, Dennis' lover, represents the 'absolutist' point of view of the conscientious objector in that he declares himself to be against 'passive pacifism' to the same extent as he is against militarism, and he condemns those individuals who take an anti-war stance and yet accept work in munitions factories or at the front line without bearing arms. To Alan, those of a pacifist point of view should be ready to suffer 'the utmost penalty' in the demonstration of their belief ('capitulating means admitting that we believe that black is white, just because the majority says so'). ${ }^{72}$ Like Bertrand Russell, he expresses the idea that the energy of populations could be channelled towards creativity rather than destruction:

Think of the heroism and self-sacrifice of those who really 'die gladly' for a mistaken idea; and the tremendous flame of patriotism that's burning in the hearts of all the peoples alike: if all these tangible and intangible splendours could have been used in the furtherance, instead of in the destruction of civilisation! ${ }^{73}$

Despised and Rejected was published by C.W. Daniel in May 1918. Daniel, a pacifist who had already been prosecuted for his publication of an anti-war pamphlet, was again prosecuted, not for obscenity (the novel featured - shockingly for the period - openly lesbian and gay characters), but as, 'likely to prejudice the recruiting of persons to serve in His Majesty's Forces, and their training and discipline'. ${ }^{74}$ Daniel was fined $£ 460$ and was forced to relinquish any unsold copies to the authorities while he declared, in a volte-face, that he would rather the book be burned than, by implication, lend support to pacifist homosexuals. Paradoxically, Stanley Unwin, who had earlier rejected the book for publication when the manuscript was offered to his firm, was one of the main contributors to the appeal launched by the Herald to help pay the fine imposed on his rival publisher. The Times Literary Supplement had described the book as well written and the author's plea for toleration open enough to, 'rob the book of any unpleasant suggestion', ${ }^{75}$ while Allatini herself hardly featured in the widely reported court case and publicity surrounding it. Sadly, her book was not published again until 1988, ten years after her death. In her The Great War and Women's Consciousness, Claire Tylee cites three principal 'pacifist' novels by women to emerge from the experience of the war: Rose Macaulay's Non-Combatants and Others, Mary Agnes Hamilton's Dead Yesterday and Despised and Rejected. Of the three, Tylee proclaims only Allatini's novel to be truly radical in its approach. The book had proved too uncomfortable in its truths for a wartime audience. Allatini obviously drew upon the real sensibilities of herself and those of people she knew to lend credence to the vivid antiwar emotions displayed in her novel. 
Storm Jameson later commented that the value of fictional accounts of personal reaction to the war lay in the fact that the experience involved the whole self - both physical and emotional - and at a time when the author was perhaps 'most sharply alive'. No other experience cut so deep into individual personality and achieved a greater level of glaring reality, and this was true in spite of varying critical opinion on the level at which individual experience became articulate fiction. Jameson believed that the war fiction of the generation of the Great War was the category of literature that would bequeath the most ultimate value to succeeding generations, in particular its power to convey the reality of the horrors of war rather than its glories. Her generation, she felt, had been without this 'prior knowledge' and thus, 'For us, and all those who like us were without the ballast of experience, the war came as a sudden wave, lifting us high before it threw us under. ${ }^{76}$ She also acknowledged that the 'gulf' of experience between women and the men who actually fought the war was 'impassable', commenting that, though, in geographical terms, the distance between her wartime home on the south coast and the Western Front was short, 'measured in human experience it is infinite'. However, she counted both herself and her brother who fought and did not survive as part of the same blighted generation, a continued blight which showed itself in a draining away of the human spirit: 'the drying up of vitality, the lack ... of resilience and warmth', concluding, 'In a year of war, the spirit lives out a lifetime of experience. ${ }^{177}$

Like Bertrand Russell, Jameson recognised that the tendency towards war involved a diversion of the peaceful human spirit via the distorted impulses of natural passions operating at a destructive level. Commercial interests, greed, false patriotism were parts of a general corruption that took hold with the arrival of the war:

War, like any powerful passion, like the passion of jealousy, begins by destroying the very source of reason. It becomes a state - of being - from which people argue, as the old astronomers argued their conception of the universe from the existence of god. Then to say, 'But this war is madness' becomes heresy and treason. ${ }^{78}$

The concepts of Russell concerning the potential of the creative and destructive impulses of society were also mirrored by the actress, journalist and author Cicely Hamilton who believed that the science of war was the enemy of progress and gradually evolving civilisation, especially when its enormous power was placed in the hands of a 'fallible and emotional humanity, liable to outbursts of passion' ${ }^{79}$ Hamilton worked in a war hospital on the edge of the forest of Chantilly for almost three years, and it was when she witnessed a hit on an ammunition dump in the Somme valley that, 'the world was suddenly changed for me', with the strange, angular silhouette of the aeroplane flying overhead representing the capabilities of a new and terrifying science of destruction. The fiery spectacle around her, she later wrote, 'made havoc of my old beliefs in progress and the onward march of humanity', and she found herself 'stunned and purposeless' for a time. 
This abrupt change in her emotional and creative life echoed the earlier effect of the start of the conflict upon Hamilton's writing, the flow of which had halted in the latter half of 1914. This stifling of creative ability did not simply affect her, as we have already seen. A literary agent later informed her how difficult it had been to procure any writing from his authors in the first few months of the war. When she inquired of the dramatist Harold Chapin, whom she encountered on a bus, how the writing of his plays was progressing, he told her there was only one thing that mattered now and gestured through the window towards the passing drill-ground of the Duke of York's barracks. Hamilton clearly identified the dangerous effect of the war upon creative impulses: 'Our morals, inevitably, are affected by the company we keep, and the machine, our constant companion, being merciless, has trained us in its own indifference. ${ }^{80}$ She only managed to find new inspiration herself in her work for the 'Concerts at the Front' organisation (linked to the YMCA and run by Lena Ashwell).

The reaction to the war of Cicely Hamilton was similar to that of another educated and observant female writer, Mary Agnes Hamilton: 'We were unprepared, morally and mentally. War in 1914 was a revelation of evil outside our categories', Hamilton wrote in her own memoir of the war. She recalled that there had been no talk of the concept of peace in the years before 1914 because there had been little talk of war to inspire it: war had seemed very remote and unreal and hence the outbreak of the conflict in 1914 had carried with it:

the force of a bomb which blasted us, suddenly, violently and with acute pain, out of our habitual thinking, broke up our patterns and violated our standards. It was a charge of dynamite applied not only to the forms of our lives but to the ideas by which we have lived. ${ }^{81}$

Mary Agnes Hamilton - feminist, suffragist and early member of the UDC was the author of Dead Yesterday (1916), another of Claire Tylee's three principal pacifist novels by women to emerge from the war. ${ }^{82}$ In common with Frances Partridge and Helen Wedgwood, Hamilton had attended Newnham College, where she had read and appreciated G.E. Moore's Principia Ethica and remembered that arguments over the nature of the concept of good were very much 'in vogue' at the time at Cambridge and that J.E. McTaggart had also been regarded as 'a major prophet'. She had also read and been impressed by Bertrand Russell's 1903 essay 'The Free Man's Worship' at a time when her and her friends were extremely critical of their own attitudes and those of the world around them and were, in Hamilton's words, 'chockfull of conscience, social and individual'. When war came she was on the staff of the Economist under the editorship of F.W. Hirst (one of Foreign Secretary Sir Edward Grey's harshest critics). Although she had previously joined the Independent Labour Party which now condemned secret diplomacy as the root cause of the war but placed Germany in the moral wrong for its violation of Belgium, Hamilton admitted that her resistance to the war was 'primarily emotion'. For her, a 'just war' was a contradiction in terms and to declare the war inevitable, 'was to 
abandon reason and proclaim despair'. She saw the war, with its 'high sensationalism', as an artificial creation with all the 'jarring suddenness of a theatrical transformation scene' and was appalled by the way in which the 'elevated chatter of publicists and parsons' masked what she saw as a universal pretence in denying the sufferings of those at the front.

In common with other female commentators, Mary Agnes Hamilton recognised the gap between those experiencing the conflict at first hand and those whose exposure to it was controlled by censored letters and deadlines. She described this gap as being like a smokescreen, 'dense, hot and excited', which divided those at home from the soldiers who, unable to impart the true horror, 'locked their fearful experiences in their breast'. Hamilton felt unable and unwilling to take part in what she described as a 'mass conversion' to the acceptance of war; the very phrase 'belief in war' now had a 'remote, unnatural ring' to it, especially those, like Hamilton, who refused to swim with the tide of war. 'We refused to un-say and un-think what we had thought before about war itself: insisted that, having happened, it was still horrific ... we alone felt the war, realised its horror, minded it; were kept awake by it. ${ }^{83}$

In 1916, Hamilton left the Economist with Hirst and both moved to Common Sense, based at 44 Essex Street and which was, as Hamilton described it, 'a sort of pacifist G.H.Q.' It was at this point that she began to write Dead Yesterday ('inspired by an intense feeling against the war') as well as numerous anti-war speeches and articles until the 'dark waters' that she felt had closed over her head in 1914, submerging and stifling her, finally receded in 1918 ('we were in the air'), although she commented that the gaiety which followed the end of the war was 'all unthinking'.

It was all so different from the state of the world at the war's beginning. Although united on the question of female suffrage, many women were naturally divided in their response to the war. Some of the female opponents of the war, such as Catherine Marshall and Helen Wedgwood, emerged from the suffrage movement and their reaction, in common with much other female opposition to the conflict, was based on a humanistic appreciation of the value of life. Women were perhaps more likely, given their 'passive' position in society and natural role as the facilitators of life, to be individuals in whom, in Wilfrid Ewart's phrase, the 'humane spark' burned brightly.

Men were regarded by some women as aggressive warmongers, both in the form of the politician - the originator of the war - and, to a lesser extent, the soldier - the executor of military policy. By contrast, the female was seen as the life-giver, the mother of sons forced to experience violent conflict and perhaps be killed or wounded for an increasingly spurious cause. In this context, the soldier could be seen as merely a dumb instrument, reduced to the level of a child - hence perhaps the protective role adopted and the terminology employed ('my boys' etc.) by women in their roles as nurses. In their specifically humanistic approach to the apparent wrongness of the war, we have seen how 
certain women of differing circumstances articulated not only a similar reaction to the conflict but also similar themes of reaction to some of the (male) individuals covered in the previous chapters. In common with some of the male writers and commentators (in particular Owen and Sassoon), direct experience of the war was also regarded by some women as having a serious role to play in their conveying of its essential truths. It was important that a woman both could and should, in the words of Mabel St Clair Stobart, 'go forth and see for herself the dangers that threaten life', in order that she could then convey these dangers to others and also be in a better position to promote feminine/nurturing instincts through helping to channel destructive energies away from the battlefield towards more moral and social purposes - a strategy that was supported and publicly promoted by Bertrand Russell. This premise of 'the value of experience' - along with other familiar themes - were to be echoed yet further.

\section{Notes}

1 Anne Wiltsher, 'Most Dangerous Women': Feminist Peace Campaigners of the Great War (London, 1985), p. 1.

2 Sylvia Pankhurst, The Home Front (London, 1932), p. 369.

3 Wilfrid Ewart, When Armageddon Came (London, 1933), pp. 360-1. See also Ewart's bestselling novel, Way of Revelation (1921) in which similar concerns are explored.

4 Contained in Women and Peace - Theoretical, Historical and Practical Perspectives, ed. R.R. Pierson (London, 1987).

5 Imperial War Museum (IWM hereafter), file of Mrs H. Pease, 76/179/1.

6 IWM, Sound Archive, Helen Bowne Pease, transcript 821/20.

7 Ibid., p. 49.

8 She was particularly close to George Horwell, an 'absolutist' and man of extreme principles who often mentioned to her in his letters of his concern that the public should be kept fully aware of the difference between the 'absolutists' and the 'Scheme men' (those that had accepted alternative work under the Home Office Scheme). He had asked her to take over his job as secretary of the Stoke NCF when he was arrested and court martialled in May 1916 after organising two outdoor anti-conscription meetings and calling publicly for an immediate peace. Horwell subsequently spent time in Whittington Barracks at Litchfield, Perth Penitentiary, Wormwood Scrubs, and prisons at Durham, Newcastle and Wakefield, where he was part of a committee which voted not to accept new conditions proposed by the authorities ('They prove to be the Home Office Scheme in another form ... I am not prepared to do compulsorily what I refused to do voluntarily two years ago', he wrote to Wedgwood - IWM, file of Mrs H. Pease, letter from G. Horwell, Sept. 1918). By August 1918, Horwell had served a total of 27 months in prison in between various courts martial and his release due to ill health. Throughout, Wedgwood corresponded with him, sent him items such as a German dictionary and Norman Angell's The Great Illusion and provided financial assistance to his mother and brother Harry, who was also imprisoned for some of the war as a conscientious objector.

9 Sarah Macnaughton, A Woman's Diary of the War (London, 1915), p. 168.

10 Sarah Macnaughton, My War Experiences on Two Continents, ed. Mrs L. Salmon (London, 1919), Preface, p. xi.

11 Ibid., 21 Oct. 1914, p. 34.

12 Ibid., spring 1915, pp. 103, 113. 
13 Ibid., April 1915, p. 115.

14 Ibid., 16 Oct. 1914 , pp. 30-1.

15 Mrs Alec-Tweedie, A Woman on Four Battle-Fronts (London, 1919), p. 35.

16 Kathleen Burke, The White Road to Verdun (London, 1916), pp. 49-50.

17 Alec-Tweedie, Woman on Four Fronts, p. 18. For more on the perspective of Mrs AlecTweedie, see Sharon Ouditt, 'Tommy's Sisters: the Representation of Working Women's Experience', in Facing Armageddon - The First World War Experienced, ed. H. Cecil and P. Liddle (London, 1996).

18 Burke, White Road, p. 50.

19 Dorothy Cator, In a French Military Hospital (London, 1915), pp. 89, 95-8.

20 Olive Dent, A VAD in France (London, 1917), pp. 25-6.

21 For example, see C.E. Jacob, Torment (London, 1919), a personal reminiscence which combined jingoism with criticism of army bureaucracy and Gilbert Frankau, Peter Jackson, Cigar Merchant: a Romance of Married Life (London, 1920), a patriotic war novel which reflected the stance of its author.

22 WAAC, The Woman's Story of the War (London, 1930), p. 35.

23 May Sinclair, Journal of Impressions in Belgium (London, 1915), p. 16.

24 Helen Zenna Smith (pseud. of Evadne Price), Not So Quiet: Stepdaughters of War (New York, 1989, first published 1930), pp. 30-1.

25 Ibid., pp. 163-4.

26 Ibid., pp. 216-17.

27 Mary Borden, The Forbidden Zone, (London, 1929), pp. 121-2. The Forbidden Zone was a collection of poems and narrative sketches from the 1914-18 period as well as stories written during the post-war period.

28 Ibid., p. 54.

29 Ibid., pp. 24-9.

30 Maude Onions, A Woman at War (published privately in 1928; then by C.W. Dent, London, 1929), pp. 17-18.

31 Ibid., p. 22.

32 Enid Bagnold, Diary Without Dates (London, 1978, first published 1918), p. 6.

33 Ibid., p. 104.

34 Ibid., p. 24.

35 Yvonne A. Bennett, 'Vera Brittain and the Peace Pledge Union' in R.R. Pierson (ed.), Women and Peace-Theoretical, Historical and Practical Perspectives (London, 1987), p. 193.

36 See Deborah Graham, 'Vera Brittain, Flora Macdonald Denison and the Great War: The Failure of Non-Violence' in Pierson, Women and Peace, pp. 142-3.

37 Vera Brittain, Chronicle of Youth - War Diary 1913-17 , ed. Alan Bridges (London, 1981), 19 April 1915, pp. 179-80.

38 Ibid., 30 Jan. 1916, p. 313.

39 Ibid., pp. 99-103.

40 Ibid., p. 163.

41 Vera Brittain, 'From War to Pacifism' quoted by Bennett in Pierson, Women and Peace, p. 193.

42 Cited in Brittain, Chronicle of Youth, ed. Bridges, 25 April 1915, p. 184.

43 Ibid., 7 Oct. 1915, p. 286.

44 Mabel Dearmer, Letters From a Field Hospital (London, 1916), pp. 157-8.

45 Ibid., pp. 158-9.

46 Stephen Gwynn, 'Memoir' in Dearmer, Letters, pp. 2-4.

47 Mabel St Clair Stobart, Miracles and Adventures (London, 1935), p. 147.

48 Although writing from a different context, the Fabian Beatrice Webb also recognised a 'return to barbarism' heralded by the war. Though she had little sympathy with the plight of the conscientious objectors (even though the noted CO Stephen Hobhouse was her nephew), Webb exhibited a horror of the escalating casualty lists which resulted in a mounting pessimism. 
She also recognised - in common with Bertrand Russell - malign impulses at work: 'I see the fine energy and cheerful self-sacrifice, the eager self-effacement of our recruits', she wrote to Lady Betty Balfour in December 1914, 'but it is a tragedy these splendid qualities should be insolubly connected with all the vulgar impulses of national domination, delight in the loss and suffering of other races, and in many cases with the horrors of lust to kill and injure individually. It is after all a return to barbarism - to animal pugnacity; and the heroism of the trenches has its likeness in the heroism of the wild animal.' B. Webb to Lady Betty Balfour, 8 Dec. 1914, cited in Carole Seymour-Jones, Beatrice Webb - Woman of Conflict (London, 1992), p. 289.

Webb also wrote in her diary of an 'indescribable torrent of misery and bestiality' which she perceived as affecting those individuals caught up in the fighting. 'This was seems a universal bankruptcy of human intelligence and human goodwill', she concluded. See The Diary of Beatrice Webb-Volume Three: 1905-1924, The Power to Alter Things , ed. Norman and Jean MacKenzie (London, 1984), p. 289. The missing body of another of Webb's nephews, Noel Williams, was found three weeks before the Armistice.

49 Mabel St Clair Stobart, A Flaming Sword in Serbia and Elsewhere (London, 1916), p. vii.

50 Ibid., pp. 311-12.

51 Ibid., p. 314.

52 Claire Tylee, The Great War and Women's Consciousness (London, 1990), p. 37.

53 Barbara McLaren, Women of the War (London, 1917), p. 32.

54 Stobart, Flaming Sword, pp. viii, 4.

55 Ibid., p. 311.

56 Caroline Playne, Britain Holds On 1917-1918 (London, 1933), p. 430.

57 Storm Jameson, No Time Like the Present (London, 1953), p. 148.

58 A.T. Fitzroy (pseud. of Rose Allatini), Despised and Rejected (London, 1988, first published 1918), p. 151.

59 Ibid., p. 169.

60 Ibid., p. 188.

61 Ibid., p. 194.

62 Ibid., p. 150.

63 Ibid., p. 150.

64 Ibid., p. 199.

65 Ibid., p. 200.

66 Ibid., pp. 194-5.

67 Ibid., pp. 317-18.

68 Ibid., pp. 317-18.

69 Ibid., pp. 241-2.

70 Ibid., p. 244.

71 Ibid., p. 157.

72 Ibid., p. 288.

73 Ibid., p. 240.

74 Ibid., cited by Jonathan Cutbill in his Introduction to the 1988 edition.

75 Ibid., cited by Cutbill.

76 Jameson, No Time, p. 189.

77 Ibid., p. 100.

78 Ibid., p. 207.

79 Cicely Hamilton, Life Errant (London, 1935), p. 150. Hamilton was the author of the war novel William -An Englishman (London, 1919).

80 Ibid., p. 152.

81 Hamilton, Remembering My Good Friends, p. 63.

82 Tylee, Great War, p. 119.

83 Hamilton, Remembering My Good Friends, p. 68. 